\title{
Some haematological observations in cardio- pulmonary bypass at normothermia using the Melrose oxygenator
}

\author{
R. A. CUMMING, S. H. DAVIES, K. KAMEL, ${ }^{1}$ G. J . \\ MACKENZIE, A. MASSON, AND J. D. WADE \\ From the Cardiopulmonary Bypass Unit, The Royal Infirmary, Edinburgh
}

Haemostasis is now generally accepted to be a dynamic mechanism. In injury, haemostasis is effected by a series of processes resulting finally in the formation of a blood clot. This process involves capillary retraction whereby the severed vessel end is narrowed; this is followed by the accretion of an occlusive platelet thrombus, and finally the formation of a clot in the now static blood. Progression of this process is probably limited and controlled by the increased production of antithrombin (and probably of other natural inhibitors), and by the fibrinolytic mechanism so that thrombus formation does not undergo retrograde spread to involve the whole vascular tree. The fibrinolytic mechanism is also reparative and is active in the healing process. In normal health a fine balance between the haemostatic and fibrinolytic systems is said to maintain the integrity of the organism (Mole, 1948 ; Copley, 1954 ; Astrup, $1956 \mathrm{a}$ and $\mathrm{b}$; Jensen, 1956).

The clotting process is a complex series of reastions in three main stages (Fig. 1). These stages involve the production of intrinsic thromboplastin, which activates prothrombin to thrombin, and this in turn converts fibrinogen to fibrin.

The fibrinolytic system produces plasmin from the soluble globulin precursor plasminogen in the blood. This reaction is controlled by activators which are present in the blood and tissues, and the active enzyme is released in excess at the site of injury. The plasmin so produced normally degrades fibrin (Fig. 2).

An insufficiency of one or more of the clotting factors can occur from (1) consumption, because inadequate anticoagulation may allow clot formation to occur, and (2) destruction, by an excessively activated fibrinolytic mechanism. Either may lead to a haemorrhagic state.

Because more platelets are required to produce 1On a study grant from Ain-Shams University, Cairo
FIG. 1. The clotting process.

Stage 1. Production of intrinsic thromboplastin or prothrombin activator

Hageman factor (factor XII)-activated by contact with damaged vessel

Plasma thromboplastin antecedent (factor XI)

Antihaemophilic factor (factor VIII)

Christmas factor (factor IX)

Factor V (labile factor)

Stuart-Prower factor (factor X)

Platelet factor 3 (co-factor 3)

$\mathrm{Ca}^{++}$

Stage 2. Thrombin formation

Prothrombin Intrinsic

Thrombin

thromboplastin

Stage 3. Fibrin clot

Fibrinogen Thrombin Fibrin

FIG. 2. The fibrinolytic system.

$\begin{array}{lll}\begin{array}{l}\text { Plasminogen } \\ \text { (profibrinclysin) }\end{array} & \text { Activators } & \begin{array}{l}\text { Plasmin } \\ \text { (fibrinolysin) }\end{array} \\ \text { Fibrin } & \text { Plasmin } & \begin{array}{l}\text { Fibrin degradation } \\ \text { products }\end{array}\end{array}$

an adequate platelet thrombus than to provide enough platelet co-factor 3 in the clotting process, thrombogenesis is impaired earlier than clotting in the presence of thrombocytopenia.

In extracorporeal circuits the maintenance of $N$ an incoagulable blood requires the addition of an $N$ anticoagulant, heparin being customarily used for $\sigma$ this purpose. Post-operatively, the anticoagulant effect of heparin is reversed by an antagonist such as hexadimethrine bromide so that normal haemo- $\stackrel{\mathcal{D}}{\rightarrow}$ stasis is restored.

Reports on changes in the coagulation mechanism after the use of an extracorporeal circulation $\stackrel{\odot}{\mathbb{D}}$ are numerous and variable, a reduction in $\vec{\Phi}$ platelets being the commonest change recorded $\frac{0}{0}$ 
(Bloom, 1961). Fibrinogenopenia and excessive fibrinolysis, although frequently described, have not been inevitable (Osborn, MacKenzie, Shaw, Perkins, Hurt, and Gerbode, 1956). Depression in blood factor VIII levels (Hoeksema, Mustard, and Mustard, 1959 ; Smith, Brown, Young, and Sealy, 1959) has not been constant (Bloom, 1961; Matzke, Jensen, and Rygg, 1961), although Perkins, Harkins, Gerbode, Rolfs, and Acra (1961) demonstrated a striking decrease in factor VIII experimentally after the administration of hexadimethrine bromide in large doses to dogs. Many of the haematological variations seemed to be dependent on techniques employed during the procedure. Here we report attempts to achieve adequate anticoagulation in cardiopulmonary bypass and to restore normal haemostasis at the end of operation and in the post-operative period.

\section{MATERIALS}

Three groups of subjects were studied.

GROUP I Thirty-two mongrel dogs of both sexes. ranging in weight from 10.5 to $23.8 \mathrm{~kg}$., were subjected to cardiopulmonary bypass.

GROUP II Ten children, aged 4 to 14 years, whose surface area ranged from 0.68 to $1.37 \mathrm{~m}^{2}$, underwent cardiopulmonary bypass for the repair of ventricular septal defects, one additionally having congenital pulmonary stenosis. Particulars relevant to these patients are shown in Table $I$.
GROUP III This group consisted of 36 mongrel dogs of both sexes, ranging in weight from $9 \cdot 7$ to $26.3 \mathrm{~kg}$. Of these, six were subjected to anaesthesia only, 10 to anaesthesia and thoracotomy, and 20 to standard cardiopulmonary bypass.

\section{METHODS}

The method of extracorporeal circulation, using a Melrose N.E.P. rotating disc oxygenator, has previously been described (MacKenzie, Davies, Masson, and Wade, 1963).

Healthy mongrel dogs were used as blood donors in the animal experiments. After heparinization $(3 \mathrm{mg}$. kg.) they were exsanguinated under anaesthesia. Blood was collected under sterile conditions through plastic cannulae into siliconed M.R.C. bottles; the anticoagulant used was $30 \mathrm{mg}$. heparin in $15 \mathrm{ml}$. sterile normal saline, $400 \mathrm{ml}$. of blood being drawn into each bottle. Donations were made on the morning of operation. In the early dog experiments, donors and the operation animal were cross-matched and intermatched.

Routine human donor blood was always collected on the morning of operation, $400 \mathrm{ml}$. being drawn from each donor into similar anticoagulant and containers. The blood was kept at $4^{\circ} \mathrm{C}$. until the priming of the machine. Donors had previously been routinely screened for abnormal antibodies, cross-matched with the patient, and intermatched among themselves.

Group III dogs were used to determine the heparinneutralizing dose of hexadimethrine bromide and to determine the degree of influence, if any, of anaes-

TABLE I

COAGULATION STUDIES, BLOOD LOSS, AND DURATION OF PERFUSION IN SIX CHILDREN UNDERGOING CARDIOPULMONARY BYPASS

\begin{tabular}{|c|c|c|c|c|c|c|c|c|}
\hline & \multirow[b]{2}{*}{$\begin{array}{c}\text { Thrombin } \\
\text { Time } \\
\text { (seconds) }\end{array}$} & \multirow[b]{2}{*}{$\begin{array}{l}\text { Fibrin- } \\
\text { ogen } \\
(\mathrm{mg} \% \%)\end{array}$} & \multirow[b]{2}{*}{$\begin{array}{l}\text { Factor } \\
\text { VIII } \\
\text { (Oxford } \\
\text { units) }\end{array}$} & \multirow{2}{*}{$\begin{array}{c}\text { Euglo- } \\
\text { bulin } \\
\text { Lysis } \\
\text { Time } \\
\text { (min.) }\end{array}$} & \multirow[b]{2}{*}{$\begin{array}{l}\text { Anti- } \\
\text { fibrin- } \\
\text { olysins } \\
\text { (titre) }\end{array}$} & \multirow[b]{2}{*}{$\begin{array}{l}\text { Duration } \\
\text { of Per- } \\
\text { fusion } \\
\text { (min.) }\end{array}$} & \multicolumn{2}{|c|}{ Blood Loss (ml./kg.) } \\
\hline & & & & & & & $\begin{array}{c}\text { Day of } \\
\text { Operation }\end{array}$ & $\begin{array}{c}\text { First } \\
\text { Day } \\
\text { Post-op. }\end{array}$ \\
\hline & \multicolumn{8}{|c|}{ F. 4 yr., 17 kg., ventricular septal defect } \\
\hline \multirow[t]{2}{*}{$\begin{array}{l}\text { Post-anaesthetic } \\
\text { At end of perfusion } \\
\text { Post-hexadimethrine bromide }\end{array}$} & $\begin{array}{l}11 \\
48 \\
12\end{array}$ & $\frac{220}{195}$ & \begin{tabular}{|c}
$62^{1}$ \\
$\quad 100$ \\
$\quad 75$
\end{tabular} & $\begin{array}{r}135 \\
60 \\
140\end{array}$ & $\begin{array}{l}1 / 14 \\
1 / 10\end{array}$ & 40 & 40 & 0 \\
\hline & \multicolumn{8}{|c|}{ F. 9 yr., $26.25 \mathrm{~kg} .$, ventricular septal defect } \\
\hline \multirow[t]{2}{*}{$\begin{array}{l}\text { Post-anaesthetic } \\
\text { At end of perfusion } \\
\text { Post-hexadimethrine bromide }\end{array}$} & $\begin{array}{l}10 \\
60 \\
10\end{array}$ & $\begin{array}{l}300 \\
261 \\
262\end{array}$ & $\begin{array}{c}114^{1} \\
69 \\
88\end{array}$ & $\begin{array}{r}>580 \\
295 \\
280\end{array}$ & $\begin{array}{l}1 / 16 \\
1 / 16 \\
1 / 18\end{array}$ & 31 & 20 & 3 \\
\hline & \multicolumn{8}{|c|}{ M. 8 yr., $22.5 \mathrm{~kg} .$, ventricular septal defect } \\
\hline \multirow[t]{2}{*}{$\begin{array}{l}\text { Post-anaesthetic } \\
\text { At end of perfusion } \\
\text { Post-hexadimethrine bromide }\end{array}$} & $\begin{array}{l}10 \\
60 \\
10\end{array}$ & $\begin{array}{l}235 \\
288 \\
180\end{array}$ & $\begin{array}{l}92^{1} \\
69 \\
80\end{array}$ & $\begin{array}{r}>488 \\
305 \\
430\end{array}$ & $\begin{array}{l}1 / 20 \\
1 / 18 \\
1 / 20\end{array}$ & 47 & 40 & 5 \\
\hline & \multicolumn{8}{|c|}{ M. $13 \mathrm{yr} ., 33.5 \mathrm{~kg} .$, ventricular septal defect } \\
\hline \multirow[t]{2}{*}{$\begin{array}{l}\text { Post-anaesthetic } \\
\text { At end of perfusion } \\
\text { Post-hexadimethrine bromide }\end{array}$} & $\begin{array}{l}10 \\
25 \\
10\end{array}$ & $\begin{array}{l}231 \\
199 \\
141\end{array}$ & \begin{tabular}{|c|c|}
$100^{1}$ \\
100 \\
88
\end{tabular} & $\begin{array}{r}>360 \\
138 \\
33\end{array}$ & $\begin{array}{l}1 / 6 \\
1 / 8 \\
1 / 6\end{array}$ & 24 & 43 & 34 \\
\hline & \multicolumn{8}{|c|}{ M. $12 \mathrm{yr} ., 30.5 \mathrm{~kg} .$, ventricular septal defect and pulmonary stenosis } \\
\hline \multirow[t]{2}{*}{$\begin{array}{l}\text { Post-anaesthetic } \\
\text { At end of perfusion } \\
\text { Post-hexadimethrine bromide }\end{array}$} & $\begin{array}{l}11 \\
60 \\
10\end{array}$ & $\begin{array}{l}195 \\
236 \\
137\end{array}$ & $\begin{array}{l}100^{1} \\
103\end{array}$ & $\begin{array}{r}270 \\
145 \\
95\end{array}$ & $\begin{array}{l}1 / 10 \\
1 / 12 \\
1 / 16\end{array}$ & 85 & 33 & 8 \\
\hline & \multicolumn{8}{|c|}{ M. $11 \mathrm{yr} ., 28.5 \mathrm{~kg} .$, ventricular septal defect } \\
\hline $\begin{array}{l}\text { Post-anaesthetic } \\
\text { At end of perfusion } \\
\text { Post-hexadimethrine bromide }\end{array}$ & $\begin{array}{l}10 \\
48 \\
11\end{array}$ & $\begin{array}{l}289 \\
149 \\
213\end{array}$ & $\begin{array}{l}91^{1} \\
68 \\
87\end{array}$ & $\begin{array}{r}>360 \\
81 \\
228\end{array}$ & $\begin{array}{l}1 / 8 \\
1 / 24 \\
1 / 24\end{array}$ & 50 & 30 & 3 \\
\hline
\end{tabular}


thesia alone, of anaesthesia with surgery, and finally of anaesthesia with bypass on this ratio.

Subjects, both dog and human, were heparinized immediately before cannulation of the venae cavae, using $3 \mathrm{mg}$. $/ \mathrm{kg}$. body weight. Hexadimethrine bromide was given approximately one to one-and-a-half hours after heparinization in all groups, the drug being administered diluted in 100 to $200 \mathrm{ml}$. $5 \%$ dextrose and given over not less than 10 minutes to avoid circulatory upset (MacKenzie, Wade, Davies, and Zellos. 1961). Additional doses were given as indicated in a similar manner. Neutralization of heparin was thought to be complete when the thrombin time had returned to the approximate preheparinization level and was not further shortened by the prior addition of toluidine blue to the plasma (Rothnie and Kinmonth, 1960b). In all other experiments hexadimethrine bromide was used in the same manner, and adequacy of neutralization was determined by the same criteria.

All the subjects. both animal and human, had a full preliminary blood count and were investigated by determination of their clotting times both in plain and in siliconed glass tubes, their prothrombin time, prothrombin consumption index, thrombin time before and after toluidine blue, Russell's viper venom time, thromboplastin generation test, and in some animals (and in all the humans) by assaying the blood factor VIII level. Bleeding time and Hess test were done in humans. Some of these parameters were repetitively monitored throughout the operation. During perfusion heparinization was thought to be adequate when a thrombin time of not less than 60 seconds (the control being 10 to 12 seconds) and a clotting time (Lee and White) of not less than 60 minutes were found. At the end of perfusion a full coagulation screening was done, and repeated, if necessary, until reversal with hexadimethrine bromide was considered complete. Thereafter a modified haematological and coagulation screening was repeated as required on the day of operation and then at regular intervals for 14 days post-operatively.

Standard blood counts were done according to the methods of Dacie (1956). The glass and silicone-treated glass clotting times, Ivy bleeding time, Hess test, Quick prothrombin time, prothrombin consumption index. thrombin time before and after toluidine blue, and recalcification time of oxalated plasma were done by the methods of Biggs and Macfarlane (1962). Russell's viper venom time was done according to Fullerton (1940) and factor VIII assay and thromboplastin generation test as described by Biggs, Eveling, and Richards (1955) and Biggs and Douglas (1953) respectively. The 'fibrinolytic' and/or 'activator' activity was measured by a plasma euglobulin lysis time (Macfarlane and Pilling, 1946) giving in our laboratory a normal value of more than 80 minutes. The antifibrinolysins were measured by their ability to inhibit the action of serial dilutions of plasmin (in our case 'thrombolysin') on a clot indicator system (Biezenski, 1960). The normal range in our hands was found to be $1 / 18$ to $1 / 10$ titres. The technique of modified methods as applied in this study has been recently described (Kamel, 1963). The fibrinogen was assayed by a Kjeldahl technique ( $\mathrm{N}=200-500 \mathrm{mg} . \%)$.

The results of our experiments are summarized in the accompanying figures and tables.

\section{DISCUSSION}

Platelets occupy a central position in relation to the problem of haemostasis in cardiopulmonary $\stackrel{\circ}{\omega}$ bypass. In vivo they function in both thrombo- $\vec{x}$ genic and coagulation systems ; in the former, by undergoing viscous metamorphosis, they produce a platelet plug, and in the latter they release platelet factor 3 (co-factor 3 ), which participates in the early stages of the clotting mechanism 은 (Alexander, 1962). As long ago as 1938 Best, Cowan, and Maclean found that inhibition of $z$ viscous metamorphosis required a much larger dose of heparin than that required to inhibit the $\stackrel{\sim}{\mathcal{S}}$ release of co-factor 3 . Heparin, which is still the $\vec{\varphi}$ most suitable anticoagulant for cardiopulmonary bypass, is limited in dose by the need to neutralize it post-operatively by either protamine sulphate or hexadimethrine bromide, both of which are potentially toxic in excess, and are themselves anticoagulants in vitro in high concentrations (Preston, $\frac{\mathrm{Q}}{\mathrm{Q}}$ 1952 ; Perkins et al., 1961). The neutralizing ratio of hexadimethrine bromide, now most generally $\overrightarrow{\overrightarrow{0}}$ used as the heparin antagonist, has steadily risen since the first clinical studies by Preston, Hohf, and Trippel in 1956. These authors recommended a $0 \cdot 7: 1$ dose ratio of hexadimethrine bromide to heparin ; Weiss, Gilman, Catenacci, and Oster- $\frac{\mathrm{O}}{\mathrm{N}}$ berg (1958) advocated the increase of this dose to $1: 1$, and Rothnie and Kinmonth $(1960 \mathrm{~b})$ to $\frac{3}{3}$ $1 \cdot 5: 1$. Table II shows that even this latter dose

TABLE II

HEXADIMETHRINE BROMIDE/HEPARIN NEUTRALIZING HEXADIMETHRINE RATIO IN DOGS

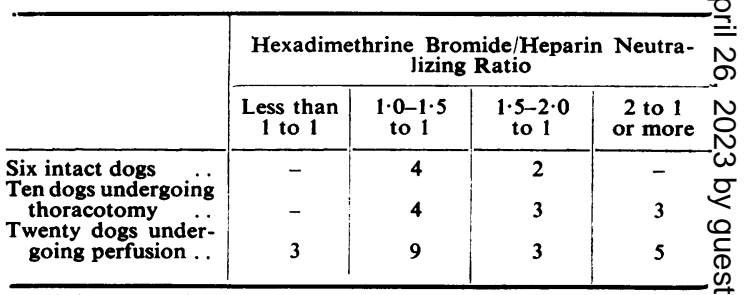

All dogs were initially given heparin in a dose of $3 \mathrm{mg} / \mathrm{kg} . \mathrm{I} . \mathrm{V}$

ratio may not always be adequate. Heparin, $30 \stackrel{\mathrm{D}}{\mathrm{D}}$ mg., in $400 \mathrm{ml}$. of blood is still inadequate to $\frac{\stackrel{\odot}{\Phi}}{\sigma}$ prevent platelet loss (Table III), and there is a $\cong$ further progressive loss on storage (Baldini, Costea, and Dameshek, 1960). It is still preferable, $\stackrel{8}{\circ}$ 
TABLE III

COMPARISON OF PLATELET LOSS IN FRESHLY DRAWN AND STORED POOLED DOGS' BLOOD USED TO PRIME 'MELROSE' HEART-LUNG MACHINE

\begin{tabular}{c|c|c|c}
\hline \multicolumn{1}{c|}{ Time Collected } & $\begin{array}{c}\text { At } \\
\text { Collection }\end{array}$ & $\begin{array}{c}\text { After Pump } \\
\text { Priming }\end{array}$ & $\begin{array}{c}\text { Percentage } \\
\text { Fall }\end{array}$ \\
\cline { 2 - 4 } $\begin{array}{l}\text { Within one hour of priming } \\
\text { On day before priming }\end{array}$ & 305 & 190 & 38 \\
\hline
\end{tabular}

Counts are in $10^{3} \mathrm{~mm}^{3}$.

The figures given in each group are the average of each of four pooled priming volumes (approximately 15 dogs in each group).

therefore, to collect blood on the morning of operation rather than the night before, and this is in agreement with recent findings (Botha and Barnard, 1962). The extensive area of foreign surface in the extracorporeal circuit, despite the effect of siliconization to reduce water wettability, produces a pronounced platelet loss through platelet adhesion even with freshly collected blood (Table III), but we found that further platelet loss does not follow proportionately to the duration of bypass (Fig. 3), in contrast to the findings of Gans and Krivit (1962). The prime loss of platelets on the distal end of the 'trombone' of the oxygenator could have serious potentialities for the patient

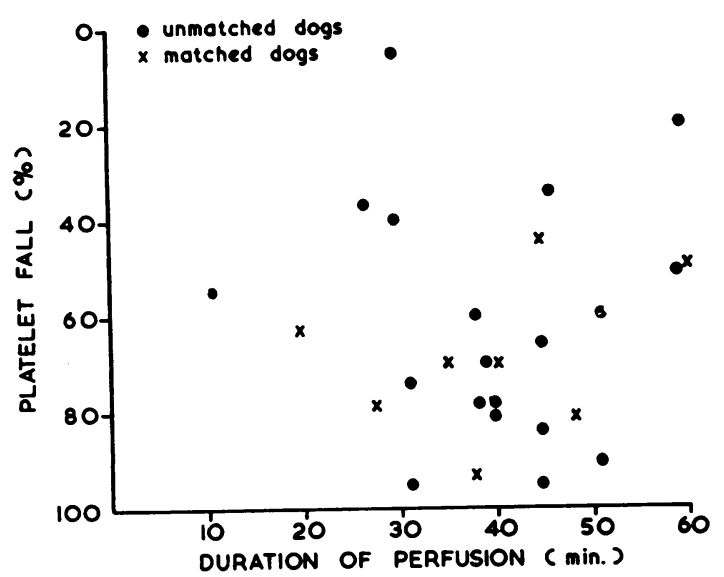

FIG. 3. Percentage fall in platelet count in dogs undergoing cardiopulmonary bypass. post-operatively by depriving him of their action in the thrombogenic phase of haemostasis. However, this platelet adhesion might also release a quantity of co-factor 3 into the extracorporeal circuit during the bypass and thereby minimally activate the coagulation mechanism with consumption of clotting factors and thus possibly activate the fibrinolytic mechanism. Neither the clotting factor loss nor the increased fibrinolysis might be evident until neutralization of heparin had been effected at the end of bypass.

The minimal platelet count post-operatively occurs at a varying time (Table IV), ranging in these four patients from day 1 to day 4-5, and this could be attributed to mechanical damage to the platelets in the pump with their subsequent shortened survival. We found no evidence, by inference from red cell compatibility tests (Table $\mathrm{V})$, that this might be a platelet antigen/antibody

T A B L E V

EFFECT ON PLATELETS OF MATCHED AND UNMATCHED PRIMING BLOOD IN DOGS UNDERGOING CARDIOPRIMING BLOOD IN DOGS UNDERG
PULMONARY BYPASS

\begin{tabular}{c|c|c|c|c}
\hline No. of Dogs & $\begin{array}{c}\text { Pre- } \\
\text { perfusion }\end{array}$ & $\begin{array}{c}\text { Mixed } \\
\text { Donor } \\
\text { Blood }\end{array}$ & $\begin{array}{c}\text { Post- } \\
\text { hexa- } \\
\text { dimethrine } \\
\text { Bromide }\end{array}$ & $\begin{array}{c}\text { Duration } \\
\text { of } \\
\text { Perfusion } \\
\text { (min.) }\end{array}$ \\
\hline fully intermatched & $\begin{array}{c}245 \\
(105-490) \\
240\end{array}$ & $\begin{array}{c}148 \\
(58-245) \\
139\end{array}$ & $\begin{array}{c}64 \\
(45-90) \\
104\end{array}$ & $\begin{array}{c}40 \\
(20-63) \\
43\end{array}$ \\
$(145-400)$ & $(39-430)$ & $(20-220)$ & $(13-62)$ \\
\hline
\end{tabular}

Counts are in $10^{3} / \mathrm{mm}^{3}$. ; ranges are given in parentheses.

reaction, and our results (Fig. 4) suggest that the red cells suffer trauma in the pump that is directly related to perfusion time, the rise in plasma haemoglobin being proportional to the length of perfusion.

A shortening of the thrombin time is indicative of loss of circulating heparin, presumably due either to its utilization or to its shift into the tissues. Thus a shortened thrombin time, if not corrected by the addition of further heparin, will presage the activation of the clotting mechanism and the consumption of clotting factors including fibrinogen and factor VIII. Using heparin in a dose

T A B L E I V

EFFECT OF CARDIOPULMONARY BYPASS ON PLATELET COUNTS IN FOUR PATIENTS

\begin{tabular}{|c|c|c|c|c|c|c|c|c|c|c|c|c|}
\hline \multirow{2}{*}{$\begin{array}{c}\text { Post- } \\
\text { anaesthesia }\end{array}$} & \multicolumn{2}{|c|}{ Perfusion } & \multicolumn{2}{|c|}{$\begin{array}{c}\text { Post-hexadimethrine } \\
\text { Bromide }\end{array}$} & \multicolumn{8}{|c|}{ Post-operative Days } \\
\hline & Beginning & End & $20 \mathrm{~min}$. & $120 \mathrm{~min}$. & 1 & 2 & 3 & 4 & 5 & 6 & 7 & 8 \\
\hline $\begin{array}{l}265 \\
195 \\
365 \\
175\end{array}$ & $\begin{array}{l}245 \\
170 \\
185 \\
190\end{array}$ & $\begin{array}{l}175 \\
110 \\
101 \\
105\end{array}$ & $\begin{array}{l}160 \\
104 \\
103 \\
105\end{array}$ & $\begin{array}{r}70 \\
124 \\
149 \\
95\end{array}$ & $\begin{array}{r}150 \\
87 \\
235 \\
120\end{array}$ & $\begin{array}{r}115 \\
87 \\
300 \\
110\end{array}$ & $\begin{array}{r}87 \\
184 \\
190 \\
88\end{array}$ & $\begin{array}{r}115 \\
240 \\
170 \\
66\end{array}$ & $\begin{array}{r}140 \\
320 \\
168 \\
92\end{array}$ & $\begin{array}{l}138 \\
340 \\
192 \\
160\end{array}$ & $\begin{array}{l}195 \\
420 \\
210 \\
360\end{array}$ & $\begin{array}{l}290 \\
435 \\
240 \\
400\end{array}$ \\
\hline
\end{tabular}

Counts are in $10^{3} \mathrm{~mm}^{3}$. 


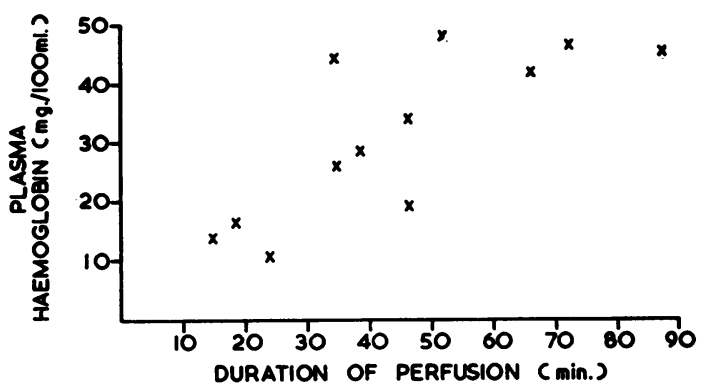

FIG. 4. Rise in plasma haemoglobin related to duration of perfusion in dogs undergoing cardiopulmonary bypass.

of $3 \mathrm{mg} . / \mathrm{kg}$. body weight (Blumberg, Winterscheid, Dillard, Vetto, and Merendino, 1960) in the patient and $30 \mathrm{mg}$. $/ 400 \mathrm{ml}$. donor blood for priming the machine, platelet loss has been a constant but not serious factor: there has been no appreciable activation of the clotting process as shown by the maintenance post-operatively of relatively normal fibrinogen and factor VIII levels (Table VI). This is in contrast with the fall in factor VIII levels described by other workers (Hoeksema et al., 1959 ; Smith et al., 1959).

Fibrinolysis has likewise been a minor problem and in no case has the total post-operative blood loss been excessive (range $23-77 \mathrm{ml}$. $/ \mathrm{kg}$., mean 43, in post-operative period). A further increase in the initial heparin dosage might therefore be advantageous were it not for the fact that the use of hexadimethrine bromide post-operatively in a 2 to 1 neutralizing ratio itself constitutes a potential hazard in that this drug can cause toxic effects in large doses. However, the thrombin time should be checked at regular short intervals while the patient is on the pump, and further doses of heparin should be given if it falls below 60 seconds.

If a shortened thrombin time heralds a minimal activation of the clotting process, it may likewise herald a compensatory activation of the fibrino- lytic mechanism. Our results show that, in two 0 out of three patients in whom the thrombin time had shortened to less than 60 seconds at the end on of bypass and who were given no further heparin, the fibrinolytic activity had increased when the heparin was subsequently neutralized, as shown by a marked fall in the euglobulin lysis time; and $\vec{\circ}$ indeed in these patients fairly rapid lysis of the whole blood clot was the first indication of it. $\stackrel{\omega}{\circ}$ However, the excess fibrinolytic activity subsided $\vec{z}$ spontaneously within 10 minutes to a level such that bleeding was not excessive.

These observations suggest that a progressive shortening of the thrombin time in the heparinized $\vec{\partial}$ patient on cardiopulmonary bypass may, if allowed $\mathrm{O}$ to continue, indicate activation of the clotting mechanism and thus the fibrinolytic mechanism so $\bar{z}$ that fibrinolysis could be a real problem as soon as heparinization has been reversed. Significant $\stackrel{\supset}{J}$ consumption of clotting factors may not have to $\vec{\oplus}$ occur to produce clinically significant fibrinolysis. The need regularly to check the thrombin time during bypass and to maintain adequate heparinization becomes obvious, and we now give additional heparin to such patients where necessary. Since instituting this régime, we have had no marked post-operative fibrinolysis and no excessive post-operative haemorrhage.

\section{SUMMARY AND CONCLUSIONS}

Our experimental work suggests that the neutralizing dose of hexadimethrine bromide for heparin should be based on a $2: 1$ ratio. The role of $\stackrel{\infty}{x}$ platelets in the haemostatic mechanism and in $\frac{5}{3}$ particular in relation to extracorporeal cardiopulmonary bypass is discussed. We suggest that $O$ adequate heparinization must be maintained to

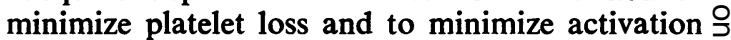
of the clotting mechanism and hence the fibrino- $\rightarrow$ lytic mechanism. We think that regular thrombin

TABLE V I

FACTOR VIII (A.H.F.) LEVELS IN PATIENTS UNDERGOING CARDIOPULMONARY BYPASS

\begin{tabular}{|c|c|c|c|c|c|c|c|c|c|c|c|}
\hline \multirow[b]{2}{*}{ Patient } & \multirow[b]{2}{*}{$\begin{array}{c}\text { Pre- } \\
\text { anaesthesia }\end{array}$} & \multirow[b]{2}{*}{$\begin{array}{c}\text { Primed } \\
\text { Blood }\end{array}$} & \multicolumn{3}{|c|}{ Perfusion } & \multicolumn{6}{|c|}{ Post-operative Days } \\
\hline & & & During & $\underset{\text { After }}{\text { Immediately }}$ & $\begin{array}{c}\text { After 2-3 } \\
\text { Hours }\end{array}$ & 1 & 3 & 4 & 6 & 8 & 10 \\
\hline $\begin{array}{r}1 \\
2 \\
3 \\
4 \\
5 \\
6 \\
7 \\
8 \\
9 \\
10\end{array}$ & $\begin{array}{l}87 \\
62 \\
92 \\
62 \\
68 \\
69 \\
90 \\
68 \\
97\end{array}$ & $\begin{array}{r}91 \\
129 \\
62 \\
79 \\
75 \\
100 \\
114 \\
92 \\
100 \\
100\end{array}$ & $\begin{array}{r}68 \\
78 \\
76 \\
101 \\
87 \\
87 \\
69 \\
69 \\
100 \\
-\end{array}$ & $\begin{array}{r}87 \\
78 \\
79 \\
75 \\
62 \\
75 \\
88 \\
80 \\
88 \\
103\end{array}$ & $\begin{array}{r}90 \\
81 \\
100\end{array}$ & $\begin{array}{r}87 \\
75 \\
81 \\
75 \\
66 \\
111\end{array}$ & $\begin{array}{l}69 \\
79\end{array}$ & $\begin{array}{r}100 \\
88\end{array}$ & $\begin{array}{r}92 \\
100\end{array}$ & 83 & $\begin{array}{r}56 \\
100 \\
75 \\
94 \\
100\end{array}$ \\
\hline
\end{tabular}

Levels of factor VIII are given in per cent of normal. 
time estimations whilst the patient is on bypass are a good indicator of the control of this process.

The authors wish to thank Miss A. Cameron, of the Blood Transfusion Service, for technical assistance. Merck Sharp and Dohme Research Laboratories, West Point, Pennsylvania, kindly supplied the 'Thrombolysin' used in the antifibrinolytic activity assays.

\section{REFERENCES}

Alexander, B. (1962). Blood coagulation and thrombotic disease. Circulation, 25, 872 .

Astrup, T. (1956a). Fibrinolysis in the organism. Analytical review. Blood 11, 781.

$(1956 b)$. The biological significance of fibrinolysis. Lancet, 2 , 565.

Baldini, M., Costea, N., and Dameshek, W. (1960). The viability of stored human platelets. Blood, 16, 1669

Best, C. H., Cowan, C., and Maclean, D. L. (1938). Heparin and the formation of white thrombi. J. Physiol. (Lond.), 92, 20

Bienzenski, J. J. (1960). Antifibrinolytic activity in normal pregnancy. J. clin. Path., 13, 220.

Biggs, R. and Douglas, A. S. (1953). The thromboplastin generation test. Ibid., 6, 23.

Eveling, J., and Richards, G. (1955). The assay of antihaemophilic-globulin activity. Brit. J. Haemat., 1, 20

and Macfarlane, R. G. (1962). Human Blood Coagulation ard its Disorders, 3rd ed. Blackwell, Oxford.

Bloom, A. L. (1961). Changes in blood after using an extracorporeal circulation. Brit. med. J., $2,16$.

Blumberg, J. B., Winterscheid, L. C., Dillard, D. H., Vetto, R. R. and Merendino, K. A. (1960). The clinical use of polybrene as an antiheparin agent in open heart surgery. J. thorac. cardiovasc. Surg., 39, 330.

Botha, M. C. and Barnard, C. N. (1962). The use of heparinized blood in open-heart surgery : a review of 250 cases. $S$. Afr. med. $J ., 36,911$.

Copley, A. L. (1954). Effet capillorragique de la fibrinolysine et de l'antifibrinolysine sur la membrane nictitante du lapin normal
et exposé aux rayons x. Arch. int. Pharmacodyn., 99, 426 .

Dacie, J. V.(1956). Practical Haematology, 2nd ed., Churchill, London.

Fullerton, H. W. (1940). Estimation of prothrombin ; a simplified method. Lancet , 2, 195.

Gans, H. and Krivit, W. (1962). Problems in hemostasis during and after open-heart surgery. VI. Over-all changes in blood coagulation mechanism. $J$. Amer, med. Ass., 179, 145.

Hoeksema, T. D., Mustard, F., and Mustard, W. T. (1959). A study of some coagulation factor changes occurring in blood during extracorporeal circulation. Presented before the American Society for Artificial Internal Organs. Atlantic City, N.J. April, 1959.
Jensen, H. (1956). Dynamic concept of fibrin formation and lysis in relation to hemorrhage (capillary permeability) and to thromin relation to hemorrhage (capill

$\mathrm{Kamel,} \mathrm{K}$. (1963). Investigations into the fibrinolytic system and haptoglobin types in certain hereditary and acquired haemostatic disorders, and the presence of circulating anticoagulants in such states. Ph.D. Thesis, University of Edinburgh.

Macfarlane, R. G. and Pilling, J. (1946). Observations on fibrinolysis. Plasminogen, plasmin, and antiplasmin content of human blood. Lancet, 2, 562 .

MacKenzie, G. J., Davies, S. H., Masson, A. and Wade, J. D. (1963). Causes of metabolic acidosis in extracorporeal circulation at normothermia. Thorax, 18, 215.

- Wade, J. D., Davies, S. H., and Zellos, S. (1961). The circulatory effects of hexadimethrine bromide (Polybrene) in dogs. Amer. Heart J., 62, 511.

Matzke, J., Jensen, R. S., and Rygg, I. H. (1961). Blood clotting problems in extracorporeal circulation. Acta chir scand. 122, 208.

Mole, R. H. (1948). Fibrinolysin and the fluidity of the blood post mortem. J. Path. Bact., 60, 413.

Osborn, J. J., MacKenzie, R., Shaw, A., Perkins, H., Hurt, R., and Gerbode, F. (1956). Cause and prevention of hemorrhage following extracorporeal circulation. Surg. Forum, 1955, 6, 96.

Perkins, H. A., Harkins, G., Gerbode, F., Rolfs, M. R., and Acra, D. J. (1961). Comparison of effects of protamine and polybrene, with special emphasis on the factor VIII (antihemophilic globulin) deficiency induced. J. clin. Invest., 40, 1421.

Preston, F. W. (1952). The antiheparin effect of polybrene. Abstracts of the proceedings of the Central Society for Clinical Research, 25th annual meeting, Chicago. J. Lab. clin. Med., 40, 927.

Hohf, R and Trippel, O. (1956). The neutralization of heparin with polybrene. Ouart. Bull. Northw. Univ. med. Sch., 30, 138.

Rothnie, N. G. and Kinmonth, J. B. (1960a). Bleeding after perfusion for open heart surgery. Importance of unneutralized heparin and its proper correction. Brit. med.J., 1, 73 . - $(1960 b)$. The neutralization of heparin after perfusion. A comparison of protamine and "polybrene". Ibid., 2, 1194.

Smith, W. W., Brown, I. W. Jr., Young, W. G. Jr., and Sealy, W. C. (1959). Studies of Edgulgate-Mg: A new donor blood anticoagulant-preservative mixture for extracorporeal circulation. J. thorac. cardiovasc. Surg., 38, 573 .

Weiss, W. A., Gilman, J. S., Catenacci, A. J., and Osterberg, A. E. (1958). Heparin neutralization with polybrene administered intravenously. J. Amer. med. Ass., 166, 603.

\section{ADDENDUM}

Since this paper was written hexadimethrine bromide has been withdrawn from the market because of possible toxic renal effects. 